
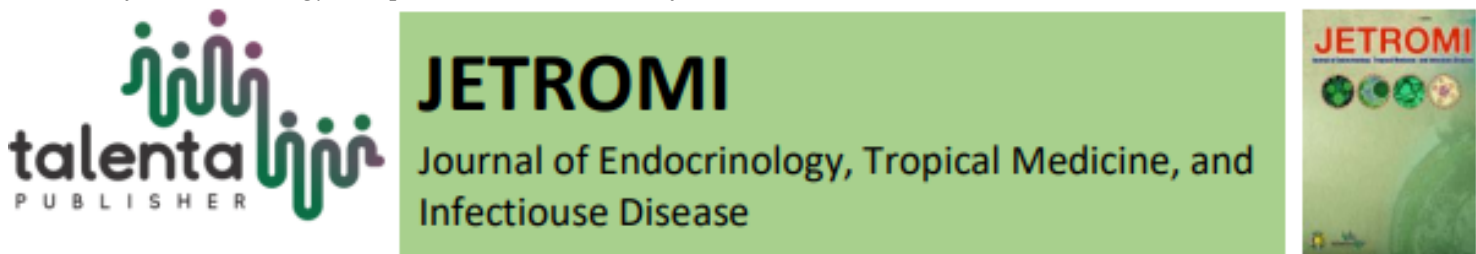

\title{
HIV Infection : What Should We Know?
}

\section{Ridwan Balatif}

Faculty of Medicine, Universitas Sumatera Utara

\begin{abstract}
Acquired Immunodeficiency Syndrome (AIDS) was first known in 1981 in homosexual groups who had opportunistic infections and malignancies. In Indonesia the first AIDS case was reported in 1987 to a Dutch citizen living in the province of Bali. Cases of HIV infection in Indonesia are reported to increase every year and most occur at the age of 25-49 years. HIV transmission is not easily transmitted, even when an HIV-infected person takes antiretroviral drugs can reduce the risk of transmission by up to $96 \%$. But one of the biggest challenges in managing HIV infection is facing stigma and discrimination. As many as 1 in 5 people living with HIV are afraid to come to the clinic because they will experience discrimination and stigma from the community if this condition occurs will cause treatment delay until PLWHA (People living with HIV/AIDS) will fall to the AIDS stage and PLWHA will be susceptible to opportunistic infections. A clinic in Namibia, when stigma and discrimination were successfully overcome, there was a $20 \%$ reduction in mortality in PLWHA.
\end{abstract}

Keyword: AIDS, Discrimination, HIV Infection, Opportunistic Infections, Stigma

\begin{abstract}
Abstrak. Acquired Immunodeficiency Syndrome (AIDS) pertama kali dikenal pada tahun 1981 pada kelompok homoseksual yang mengalami infeksi oportunistik dan keganasan. Di Indonesia kasus AIDS pertama kali dilaporkan pada tahun 1987 pada seorang warga negara Belanda yang tinggal di provinsi Bali. Kasus infeksi HIV di Indonesia dilaporkan setiap tahunnya mengalami peningkatan dan paling banyak terjadi di usia 25-49 tahun. Transmisi HIV tidak mudah menular, bahkan ketika seorang yang terinfeksi HIV mengonsumsi obat antiretroviral dapat menurunkan risiko transmisi hingga 96\%. Namun salah satu tantangan terbesar dalam menatalaksana infeksi HIV adalah menghadapi stigma dan diskriminasi. Sebanyak 1 dari 5 ODHA takut datang ke klinik dikarenakan akan mengalami diskriminasi dan stigma dari masyarakat apabila kondisi seperti ini terjadi akan menyebabkan tertundanya pengobatan hingga ODHA akan jatuh ke stadium AIDS dan ODHA akan rentan mengalami infeksi oportunistik. Suatu klinik di Namibia, ketika stigma dan diskriminasi berhasil diatasi, terjadi penurunan angka kematian pada ODHA sebesar $20 \%$.
\end{abstract}

Kata Kunci: AIDS, Diskriminasi, Infeksi HIV, Infeksi Oportunistik, Stigma

Received 01 October 2019 | Revised 09 October 2019| Accepted 16 October 2019

\footnotetext{
${ }^{*}$ Corresponding author at: Faculty of Medicine, Universitas Sumatera Utara, Jl. Dr. Mansur No. 5, Kampus USU, Medan, Sumatera Utara, Indonesia, 20155

E-mail address: b.ridwan2503@gmail.com
} 


\section{Introduction}

The case of HIV infection is one of the world's health problems. It is estimated that in 2018 around 37.9 million people will be infected with HIV. In Indonesia, cases of HIV infection have increased while for AIDS cases is relatively stable.

Acquired Immunodeficiency Syndrome (AIDS) was first recognized in 1981 when homosexual groups had opportunistic infections and rare malignancies [1]. On April 23, 1984, it was discovered that the cause of AIDS was a retrovirus called HTLV-III by Robert Gallon and tests for detecting HIV using the ELISA method were available in 1985 [2]. To date no country has been declared free from HIV / AIDS. HIV infection causes a multidimensional crisis, and this is because HIV infection causes an economic, development, health and education crisis [3].

Data from the United Nations Program on HIV / AIDS (UNAIDS) in 2018 around the world estimated 37.9 million people were infected with HIV, and around 770,000 people died from diseases that accompany HIV [4]. In Indonesia, the cumulative number of HIV infections reported up to June 2018 there were 301,959 inhabitants. The number of HIV cases reported each year continues to increase while the number of AIDS is relatively stable. This shows that more and more people with HIV / AIDS (PLWHA) are known to have HIV infection status and have not yet entered the AIDS stage [5].

Now HIV infection is not a death sentence like before. Antiretroviral Therapy (ART) treatment can provide a better chance of life and reduce the risk of HIV transmission. A study of 1763 serodiscordant couples (one person infected with HIV and his partner not infected with HIV) from 9 countries, found that early ART administration could reduce the risk of HIV transmission by $96 \%$ [6]. Research conducted by Gueler et al involving 16,532 patients HIV infection from Switzerland found that life expectancy in HIV patients aged 20 years had increased from 11.8 years in the era of HIV monotherapy to 54.9 years in the era of HIV combination therapy [7].

\section{History of HIV}

Until now it is still unknown with certainty the origin of HIV. It is suspected that the origin of HIV originated from the Simian Immunodeficiency virus (SIV) from primate animals (figure 1). Researchers suspect that SIV is transmitted to humans and mutates to HIV when humans hunt primates (such as chimpanzees) then eat the flesh and blood of infected animals [8]. 


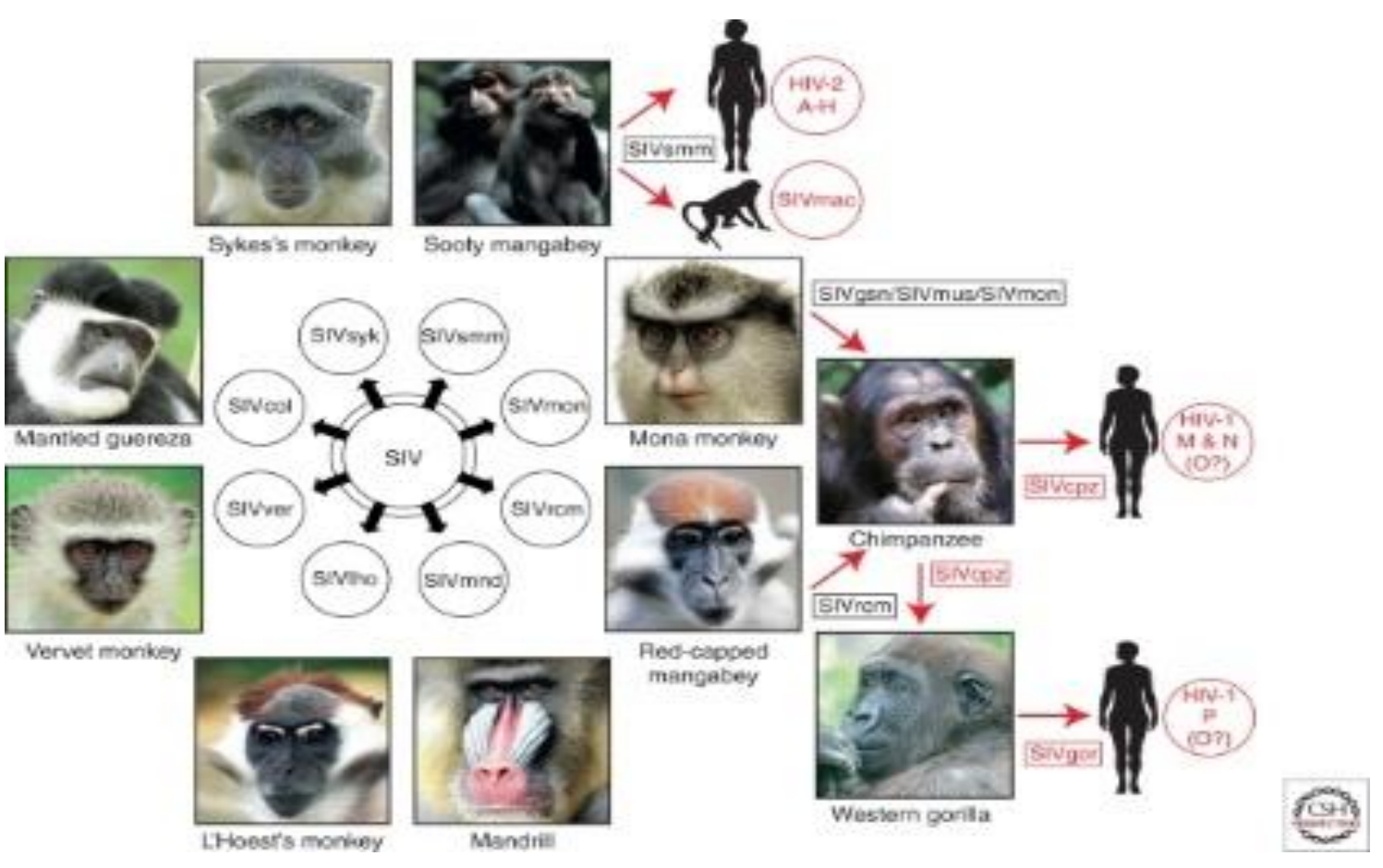

Figure 1 The origin of HIV ${ }^{1}$

At the beginning of the famous case of HIV infection began in 1981. On June 5, 1981, in Los Angeles, there were 5 cases reported by the Centers for Diseases Control and Prevention (CDC) in young (previously healthy) gay men experiencing a lung infection. Pulmonary infection that is rare is Pneumocystis carinii pneumonia (PCP). From June 5-6 of the same year, the CDC received reports of similar PCP infections and opportunistic infections (including cases of Kaposi's Sarcoma cancer) in a group of homosexuals. At the end of 1981, there were 270 cases of severe immune deficiency in the homosexual group, and 121 of them had died. Because this AIDS condition affects many homosexual groups, AIDS in its past was called Gay-Related Immunodeficiency (GRID) [2].

On December 10, 1982, the CDC reported cases of AIDS originating from infants who received blood transfusions. The following week, there were also published 22 cases of immune deficiency and opportunistic infections that were unexplained in infants. In May 1986, the International Committee on the Taxonomy of Viruses formalized the cause of AIDS is HIV [2]. In Indonesia, in March 1986, a case of HIV infection in Indonesia was found in a hemophilia patient in Cipto Mangunkusumo Hospital and was a type of non-progressor, which meant that the health and immunity of the patient was quite good for 17 years without treatment and had been confirmed by Western Blot [3]. Another case also occurred in a person who had AIDS found in a Dutch citizen in Bali Province in 1987, and this was the first AIDS case officially reported to the Ministry of Health [3, 9].

\section{Epidemiology of HIV Infection}

In 2018, it was estimated that there are 37.9 million people infected with HIV worldwide, and about 1.7 million of them are new cases of HIV infection. Of 37.9 million cases of HIV in 2018, around 1.7 million cases were experienced in children (under the age of 15 years). Since 2010, 
new cases of HIV infection have decreased by $16 \%$, from 2.1 million cases to 1.7 million cases in 2018. Surprisingly, 8.1 million people did not know that they had been infected with HIV [4]. Ignorance; this will create a delay in treatment which will worsen the condition for people with HIV.

In Indonesia alone, the cumulative number of HIV infections reported from 2005 up to 2019 is 338,363 people. From January to March 2019, there were 807,488 people taking HIV tests with 11,081 reported cases of HIV. From the Province of North Sumatra, the number of cases of HIV infection in March 2019 reached 522 cases [10]. Based on reports from the HIV / AIDS Information System (SIHA) from 2010-2019, the highest number of HIV cases were found in the age of 25-49 years (table 1).

Table 1 Percentage reported HIV infection by age group from 2010-2019 [10]

\begin{tabular}{|c|c|c|c|c|c|c|c|c|c|c|c|c|c|c|}
\hline \multirow{2}{*}{ No } & \multirow{2}{*}{ Year } & \multicolumn{12}{|c|}{ Age group (year) } & \multirow{2}{*}{ Total } \\
\hline & & $\leq 4$ & $\%$ & $5-14$ & $\%$ & $15-19$ & $\%$ & $20-24$ & $\%$ & $25-49$ & $\%$ & $\geq \mathbf{5 0}$ & $\%$ & \\
\hline 1 & 2010 & 390 & 1.8 & 405 & 1.9 & 827 & 3.8 & 3,480 & 16.1 & 15,648 & 72.5 & 841 & 3.9 & 21,591 \\
\hline 2 & 2011 & 547 & 2.6 & 242 & 1.2 & 683 & 3.2 & 3,113 & 14.8 & 15,490 & 73.7 & 956 & 4.5 & 21,031 \\
\hline 3 & 2012 & 541 & 2.5 & 208 & 1.0 & 697 & 3.2 & 2,964 & 13.8 & 15,133 & 70.4 & 1,968 & 9.1 & 21,511 \\
\hline 4 & 2013 & 759 & 2.6 & 316 & 1.1 & 1,058 & 3.6 & 4,493 & 15.5 & 20,976 & 72.2 & 1,435 & 4.9 & 29,037 \\
\hline 5 & 2014 & 1,030 & 3.1 & 358 & 1.1 & 1,101 & 3.4 & 4,894 & 15.0 & 23,512 & 71.9 & 1,816 & 5.6 & 32,711 \\
\hline 6 & 2015 & 795 & 2.6 & 338 & 1.1 & 1,119 & 3.6 & 4,871 & 15.7 & 21,810 & 70.5 & 2,002 & 6.5 & 30,935 \\
\hline 7 & 2016 & 903 & 2.2 & 406 & 1.0 & 1,510 & 3.7 & 7,154 & 17.3 & 28,602 & 69.3 & 2,675 & 6.5 & 41,250 \\
\hline 8 & 2017 & 901 & 1.9 & 425 & 0.8 & 1,729 & 3.5 & 8,252 & 17.0 & 33,448 & 69.2 & 3,545 & 7.7 & 48,300 \\
\hline 9 & 2018 & 988 & 2.1 & 459 & 1.8 & 1,434 & 3.1 & 7,068 & 15.1 & 32,847 & 70.4 & 3,863 & 8.3 & 46,659 \\
\hline 10 & 2019 & 195 & 1.8 & 113 & 1.0 & 261 & 2.4 & 1,678 & 15.1 & 7,843 & 70.8 & 991 & 8.9 & 11,081 \\
\hline
\end{tabular}

Report through SIHA as of April 15, 2019

For AIDS cases from January to March 2019, 1,536 cases were reported. AIDS cases in Indonesia are relatively stable every year. AIDS cases occur in almost all occupations. In Indonesia in 2019, as many as 547 AIDS cases occurred in employees, followed by housewives in 213 cases and AIDS cases in enterpreneur as many as 174 cases [10].

\section{HIV Infection}

HIV or Human Immunodeficiency Virus is a virus belonging to the family Retroviridae, a subfamily of Lentivirinae [11-13]. HIV is an ssRNA virus, enveloped, spherical, 80-100 nm in diameter and the HIV virion there are reverse transcriptase, protease, and integrase enzymes (figure 2) [11, 14]. HIV inactivation can occur if given $0.3 \% \mathrm{H} 2 \mathrm{O} 2,0.5 \%$ Lysol, $0.5 \%$ paraformaldehyde, 50\% ethanol, and 35\% isopropanolol. Extreme $\mathrm{pH}$ levels $\mathrm{pH} 1.0$ or $\mathrm{pH}$ 13.0) can also inactivate HIV. Also, HIV is inactivated in a liquid heated at $56^{\circ} \mathrm{C}$ for 10 minutes [14]. 


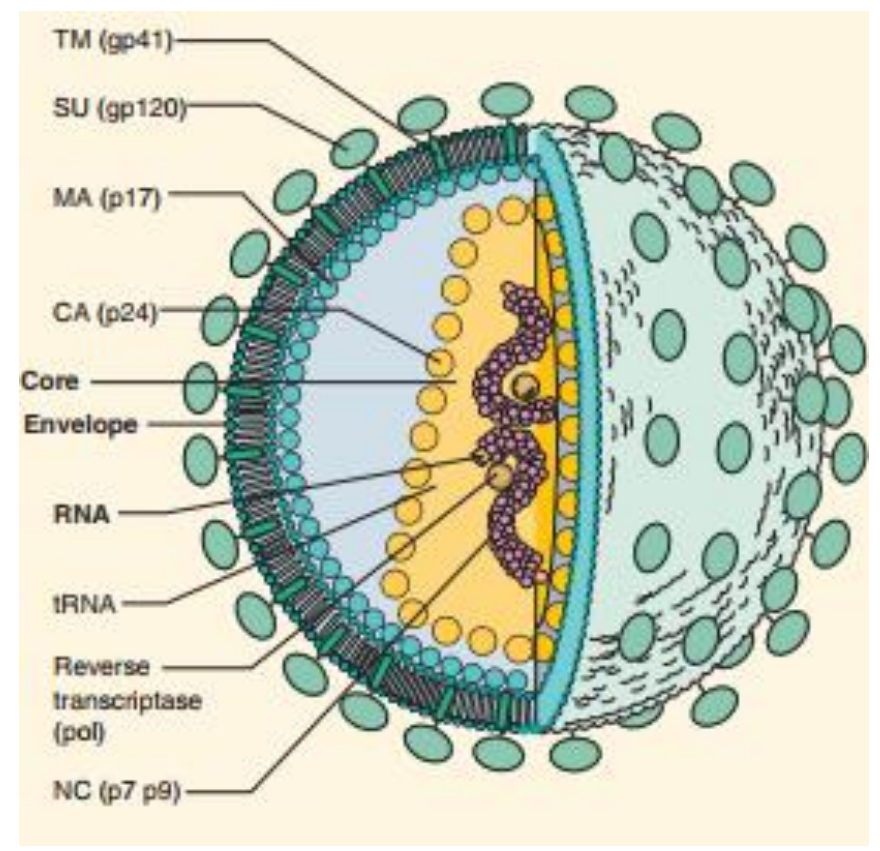

Figure 2 Structure of HIV.

Envelope surrounds a capsid that contains two identical RNA strands, reverse transcriptase, integrase and polymerase. The envelope spikes, consist of surface (SU, gp120) and transmembrane (gp41). CA, capsid; MA, matrix; NC, nucleocapsid [11]

There are two HIV serotypes namely HIV-1, and HIV-2. Infection by HIV-1 is the most common HIV infection in the whole world, while infection by HIV-2 occurs mostly in the West African region [11-14]. There is a suspicion that HIV-1 originates from SIV which infects chimpanzees while HIV-2 derived from SIV that infects sooty mangabey $[15,16]$.

They was no idea. The condition of AIDS is rarely found in someone infected with HIV -2 so that the life expectancy of someone suffering from HIV-2 is longer [17]. In several studies, the prevalence of cases of HIV-2 infection has decreased while there has been an increase in cases of HIV-1 (Table 2).

Table 2 Epidemiology comparison between HIV-1 and HIV-2 [17]

\begin{tabular}{|c|c|c|c|}
\hline Comparison & Settings/cohort & HIV-1 & HIV-2 \\
\hline Prevalence & Gambia, 1988-2003 & $\begin{array}{l}\text { Increased by } 4.2 \% \text { in } 1988 \text { - } \\
1991 \text { and } 17.5 \% \text { in } 2001- \\
2003\end{array}$ & $\begin{array}{l}\text { Decreased by } 7.0 \% \text { in } 1988- \\
1991 \text { and } 4.0 \% \text { in } 2001-2003\end{array}$ \\
\hline \multirow[t]{2}{*}{$\begin{array}{l}\text { Prevalence and } \\
\text { Incidence rate }\end{array}$} & $\begin{array}{l}\text { Guinea Bissau, 1996- } \\
2007\end{array}$ & $\begin{array}{l}\text { Increased from } 2.3 \% \text { in } 1996 \\
\text { to } 4.6 \% \text { in } 2006 \text {; incidence } \\
\text { rate of } 0.5 \text { / } 100 \text { people / year }\end{array}$ & $\begin{array}{l}\text { Decreased from } 7.4 \% \text { in } 1996 \\
\text { to } 4.4 \% \text { in } 2006 \text {; incidence } \\
\text { rate of } 0.24 \text { / } 100 \text { people / year }\end{array}$ \\
\hline & $\begin{array}{l}\text { Guinea Bissau, 1990- } \\
2007\end{array}$ & $\begin{array}{l}\text { Stable: } 4,5 / 1000 \text { people/year } \\
\text { Increased from } 0.5 \% \text { in } 1990 \\
\text { to } 3.6 \% \text { in } 2007\end{array}$ & $\begin{array}{l}1000 \text { people / year } \\
\text { Decreased from } 8.3 \% \text { in } 1990 \\
\text { to } 4.7 \% \text { in } 2007\end{array}$ \\
\hline $\begin{array}{l}\text { Vertical } \\
\text { transmission }\end{array}$ & $\begin{array}{l}\text { Portugal, between } 1999 \\
\text { and } 2005 \text { Gambia }\end{array}$ & $\begin{array}{l}\text { There was a decrease from } \\
7 \% \text { in } 1999 \text { to } 0.5 \% \text { in } 2005\end{array}$ & $1.5 \%$ over a 7 year period \\
\hline $\begin{array}{l}\text { Risk factor } \\
\text { transmission }\end{array}$ & & $\begin{array}{l}24.4 \% \text { transmission High } \\
\text { viral load, low CD4 cell }\end{array}$ & $4.0 \%$ transmission \\
\hline
\end{tabular}


Various diseases can accompany someone infected with HIV. Research conducted by Ndour et al (2000), of 790 HIV patients with 599 cases of HIV-1 infection, 137 facts of HIV-2 disease and 54 cases of HIV-1 and -2 infection, found that cases such as chronic diarrhea were more likely to attack someone those infected with HIV-2 (83\%) compared with HIV-1 (70\%) and HIV-1, -2 (78\%) infections. It is still in the same study that a person who has oral candidiasis is more likely to have an HIV-1 case (67\%) while an HIV-2 case $(58 \%)$, with the possibility of someone who is infected with HIV-1 being 1.46 times more likely to suffer from candidiasis oral [18]. Another study involving 1312 tuberculosis (TB) patients found that 241 patients were infected with HIV-1, 93 patients were infected with HIV-2 and 45 patients were infected with HIV-1, -2. From the analysis of the study, it was found that a person affected with HIV -1 had a six times higher risk of having TB, an HIV-2 infection had a chance of 2 times more upper, and HIV-1 infection, -2 a risk of 7 times higher compared to TB patients without HIV infection [19].

Phylogenetically HIV-1 can be divided into four groups, namely group M (major), O (outlier), $\mathrm{N}$ (non-M, non-O), and P. From group $\mathrm{M}$, subdivided into 11 subtypes namely from A-K. Group M HIV-1 infection is predominant throughout the world, groups; $\mathrm{O}, \mathrm{N}$, and $\mathrm{P}$ are prevalent in the Cameroon region [15]. In HIV-2 it is divided into several subtypes, namely from $\mathrm{A}$ to $\mathrm{H}[11,14,15]$. The division of these subtypes is useful to find out the distribution in the world and to assess the nature and behavior of viruses. So the potential for the emergence of drug resistance and the ability to detect HIV antibody test reagents can be known [13].

The HIV genome contains three main genes to form viral structural proteins, namely gag (specific antigen), pol (polymerase), and env (envelope). In addition there are several additional genes namely tat, rev, vif, vpu, vpr, and nef $[12,13,16]$. All of these genes have their respective roles during the process of virus replication. The function of these genes can be seen in Table 3 .

Table 3 Genes of HIV 11,16

\begin{tabular}{|c|c|c|c|}
\hline Gene & Protein & Size (kDa) & Function \\
\hline gag & $\begin{array}{l}\text { p17 } \\
\text { p24 } \\
\text { p6 } \\
\text { p7 } \\
\text { p1 } \\
\text { p2 }\end{array}$ & & $\begin{array}{l}\text { Matrix proteins, interactions with gp } 41 \\
\text { Core protein } \\
\text { Core protein, bound to vpr } \\
\text { Nucleocapsid, binds to RNA }\end{array}$ \\
\hline pol & $\begin{array}{l}\text { Protease } \\
\text { Reverse-transcriptase } \\
\text { Integrase }\end{array}$ & $\begin{array}{l}10 \\
66,51 \\
32\end{array}$ & $\begin{array}{l}\text { Proteolytic cleavage of gag and pol } \\
\text { Polymerase and RNase } \mathrm{H} \text { activity } \\
\text { Integration into chromosomes }\end{array}$ \\
\hline env & $\begin{array}{l}\text { Gp120 } \\
\text { Gp } 41\end{array}$ & & Envelope, viruses enter cells \\
\hline
\end{tabular}


Transmembrane protein, cell fusion

\begin{tabular}{|c|c|c|c|}
\hline tat & $\begin{array}{l}\text { Trans-activator of } \\
\text { transcription }\end{array}$ & 14 & Viral transactivator and immune suppression \\
\hline rev & $\begin{array}{l}\text { Regulator of expression of } \\
\text { virion protein }\end{array}$ & 19 & $\begin{array}{l}\text { Regulates the cutting of RNA and helps move it } \\
\text { to the cytoplasm }\end{array}$ \\
\hline nef & Negative regulatory factor & 27 & $\begin{array}{l}\text { CD4 downregulation; regulate the speed of virus } \\
\text { replication }\end{array}$ \\
\hline vif & Virion Infectivity Protein & 23 & Inhibits antiviral cell protein \\
\hline$v p r$ & Viral Protein R & 18 & Trigger viral replication in primary target cells \\
\hline$v p u$ & Viral Protein U & $15-16$ & $\begin{array}{l}\text { Triggers virion release from cells, } \\
\text { downregulation of } \mathrm{CD} 4 \text { and } \mathrm{MHC} \text { class I } \\
\text { expression }\end{array}$ \\
\hline
\end{tabular}

Infection starts with the bond between viral glycoprotein (trimer molecules of gp120 and gp41) with the primary receptor (CD4) and then will be tightened with one chemokine receptor namely CXCR4 or CCR5 which acts as a co-receptor (figure 3). These receptors and coreceptors are found in the plasma membranes of CD4 T lymphocyte cells, monocyte cells, Langerhans cells, dendritic cells, and some cells in the brain [20].

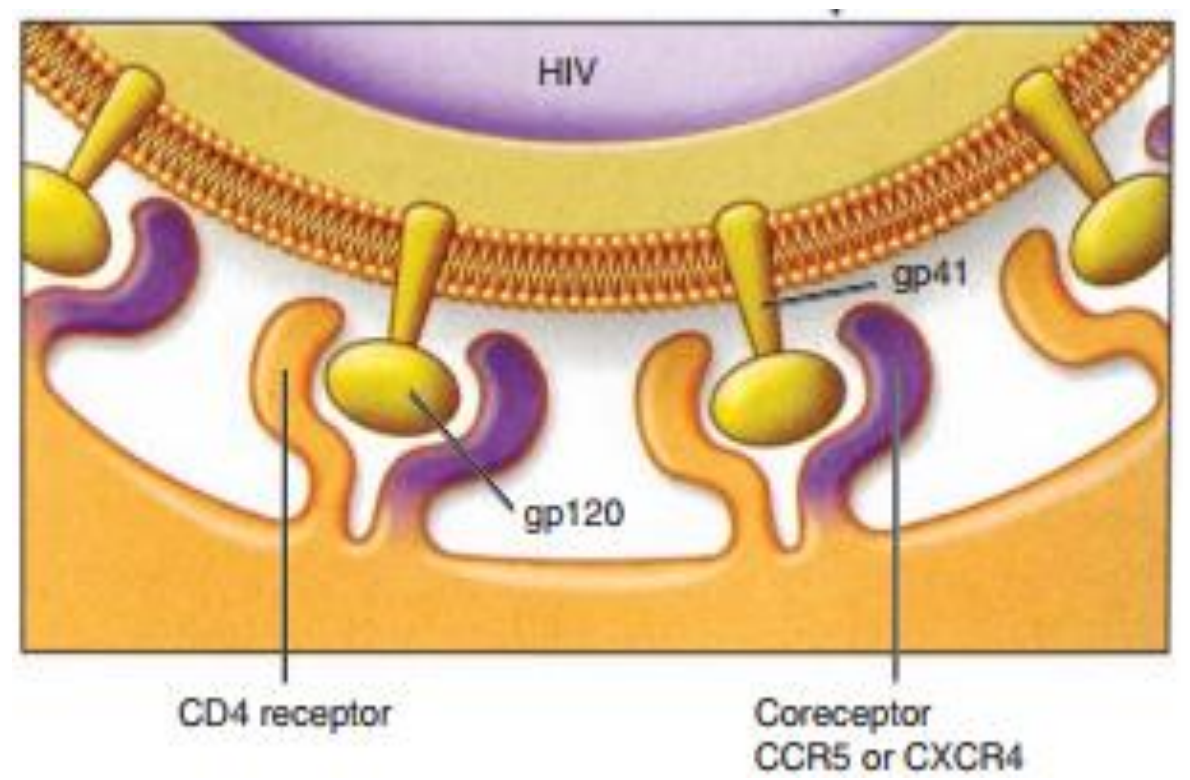

Figure 3 Viral binding with cell receptor.

HIV spikes (gp120) binds to CD4 and chemokine co-receptor. Transmembrane (gp41) is responsible for fusion between viral and cell membrane [20]

Binding with these chemokine receptors will cause cell activation and carry the viral envelope adjacent to the cell plasma membrane, gp41 will interact and create a fusion of the two layers. Immediately after the entry of the virus nucleus into the cytoplasm of infected cells, the process 
of releasing the viral core-sheath (uncoating) and viral RNA will be converted into complementary DNA (cDNA) by the work of the reverse transcriptase enzyme. Then cDNA will be converted to double-stranded DNA (dsDNA) by the action of DNA-dependent DNA polymerase from the same protein reverse transcriptase.

When dsDNA is formed, viral DNA can enter the cell nucleus through the cell nucleus pores. Then dsDNA is cut and introduced into cell DNA with the help of the integrase enzyme. This integration process requires cells when active. When integrated, viral DNA (provirus) is transcribed as a cell gene by the host's RNA polymerase II. This process forms the mRNA chain that contains the Gag, env, pol genes. Gag and pol polyproteins are cut by viral proteases whereas env polyproteins are cut by cellular proteases.

The Gag polyprotein is cut to form a core protein (p24), a matrix protein (p17) and several other small proteins. Pol polyproteins are cut to form reverse transcriptase, integrase, and protease enzymes. Immature virions are composed of polyprotein precursors formed in cytoplasm and the process of cutting by viral proteases occurs when immature virions come out of cells so they can form mature (infectious) viruses $[11,20]$. Illustration of the process of viral replication can be seen in Figure 4.

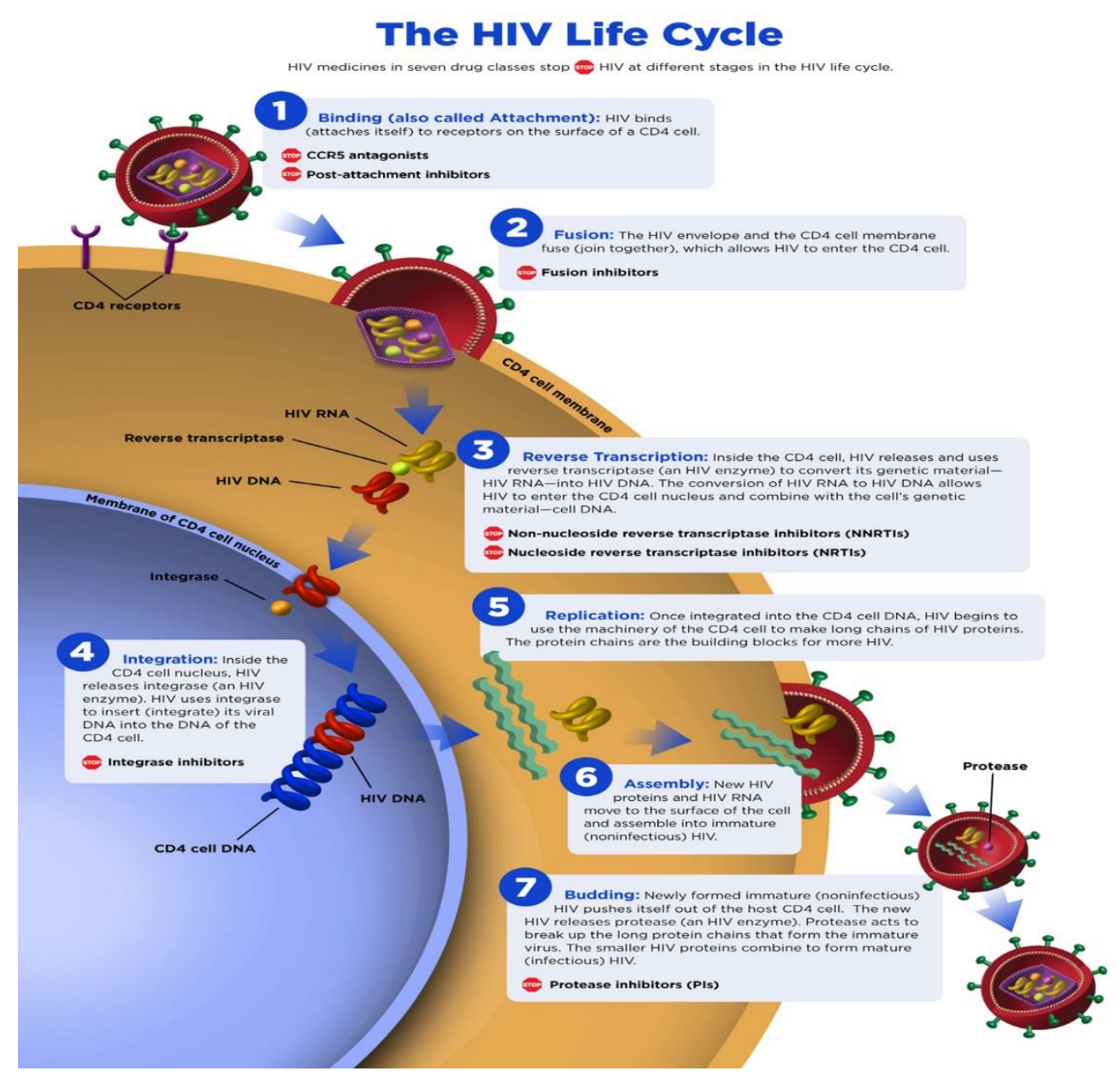


Figure 4 There are 7 main stages of HIV replication namely: Binding, HIV binds to its receptors on target cells; Fusion, HIV enters cells; Reverse Transcription, in the cytoplasm, the virus will use the reverse transcriptase enzyme to convert RNA into DNA so that it can enter the nucleus; Integration, viral DNA will join the DNA of cells; Replication, the virus will take over cells to make new virus components; Assembly, the components of the virus formed will be arranged into a complete virus; Budding, the virus (immature) will come out of the cell membrane and with the protease enzyme will break down the protein in the immature virus into maturity. Anti-HIV drugs have different mechanisms of action based on the HIV replication cycle [21]

There is a uniqueness that occurs in the population of Northern Europeans who have the CCR5delta 32 mutation. About $1 \%$ of the Eastern European population (mainly Swedish) is homozygous (inherited from both parents) to this mutation. The modification of CCR5-delta 32 will be like a "locked door" that will prevent the entry of HIV into cells. The existence of variations will reduce the risk of HIV transmission and slow the journey of infection to AIDS $[11,22]$.

\section{HIV Transmission}

The highest HIV titer can be found in two body fluids, namely blood and semen. HIV transmission occurs through bodily fluids that contain HIV, namely through sexual contact, shared needles for drug users, blood transfusions, and vertical transmission from mother to baby [3]. Data from the Drug Dependency Hospital shows that there is an increase in cases of drug users living with HIV, from $16.35 \%$ in 2012 to $28.77 \%$ in 2013 [23]. About $90 \%$ of cases of HIV infection in children are caused by HIV transmission from mother to baby. HIV transmission from mother to baby through three channels namely intrauterine, intrapartum and through breast milk [12].

HIV transmission through sexual intercourse accounts for around $70 \%$ of HIV cases worldwide [24]. The lowest risk of HIV transmission through sexual contact is through oral sex while the highest is through anal sex (Table 4). A study carried out from 1990-2000 to observe the risk of oral sex transmission among serodiscordant heterosexual couples, found that no HIV transmission was recovered from an infected partner to a healthy partner [25]. There is an explanation of a low risk of HIV transmission through oral sex due to the presence of secreted enzymes leukocyte protease inhibitors (SLPI) which can interfere with the binding process of viruses with $\mathrm{T}$ cells or macrophages. Besides, other immune systems such as $\beta$-defensins, mucin, salivary agglutinin, and immunoglobulin A ( $\operatorname{IgA})$ play a role in interfering with viral replication [26].

Table 4 Estimation of possible transmission of HIV from sources of infection on various routes $^{27}$

Exposure Risk per-10.000 exposures

Parenteral exposure 


\begin{tabular}{ll}
\hline Blood transfusion & 9250 \\
\hline $\begin{array}{l}\text { Needle sharing injection drug } \\
\text { user }\end{array}$ & 63 \\
\hline Percutaneous needle stick & 23 \\
\hline Sexual exposure & 138 \\
\hline Receptive anal intercourse & 11 \\
\hline $\begin{array}{l}\text { Insertive anal intercourse } \\
\text { Receptive penile-vaginal } \\
\text { intercourse }\end{array}$ & 8 \\
\hline $\begin{array}{l}\text { Insertive penile-vaginal } \\
\text { intercourse }\end{array}$ & 4 \\
\hline Receptive oral sex & low (0-4) \\
\hline Insertive oral sex & low (0-4)
\end{tabular}

\section{Vertical transmission}

Mother to child transmission 2260

Although the risk of HIV transmission is low through sexual intercourse, additional prevention is needed to suppress HIV transmission further. Antiretroviral treatment can reduce the risk of HIV transmission by up to $96 \%$ [6]. Other precautions such as the use of condoms, not changing partners, and circumcision can help prevent HIV transmission. A study involving 2784 men aged 18-24 years in Kenya to observe the risk of HIV transmission in circumcised men, found that circumcision can reduce transmission risk by $60 \%$ [28]. The same was found in research conducted in Africa South by involving 3274 men, that by circumcision can reduce HIV transmission by $60 \%$ [29]. WHO recommends considering circumcision as an HIV prevention effort [30].

There are several theories explaining circumcision that can reduce the risk of HIV transmission. First, the location of the superficial layer of the penis is rich in targets from HIV such as Langerhans cells, dendritic cells, and CD4 and CD8 lymphocytes and HIV can easily penetrate this layer of skin. Second, the environment of a fertile foreskin area can help the growth of microbes that can trigger inflammation and will invite HIV target cells to the foreskin area[31, 32]. 


\section{$6 \quad$ HIV Infection Staging}

Without adequate treatment, sufferers of HIV infection can continue to the AIDS stage. There are three stages in HIV infection [33], namely:

\subsection{Stage of acute infection}

This stage is the initial stage of HIV infection and occurs within 2-4 weeks after HIV infection. During this stage, sufferers will experience flu-like symptoms, such as fever, headaches, sore throats to rashes (table 6). At this stage, the virus multiplies very quickly and spreads throughout the body. At this stage also the level of HIV in the blood is very high $\left(10^{7}\right.$ particles / $\mathrm{mL}$ plasma) thereby increasing the risk of HIV transmission. CD8 T cells will kill infected cells and limit the production of viruses. When that happens, the level of the virus in the blood will decrease, and the patient will enter the chronic (asymptomatic) phase, but viral replication will continue within the lymph nodes causing damage to structure and function so that the number of CD4 T cells will continue to decline.

Table 5 Sign and symptoms in acute HIV infection [15]

\begin{tabular}{lc}
\hline Sign and Symptoms & $\begin{array}{c}\text { Percentage of patient with } \\
\text { acute HIV infection }\end{array}$ \\
\hline Fever & $55 \%$ \\
Pharyngitis & $43 \%$ \\
Myalgia & $39 \%$ \\
Diarrhea & $27 \%$ \\
Limphadenopathy & $36 \%$ \\
Nausea & $26 \%$ \\
Meningismus & $20 \%$ \\
Headache & $33 \%$ \\
Photopobia & $16 \%$ \\
Vomitting & $13 \%$ \\
Rash & $16 \%$ \\
Oropharyngeal sores & $6 \%$ \\
\hline
\end{tabular}

\subsection{Chronic HIV infection}

This stage is often called HIV asymptomatic infection or latent HIV infection. At this stage, HIV still multiplies, but its replication power decreases. At this stage, the sufferer may not experience symptoms but can still transmit the virus to others. At this time, the patient will experience an increase in viral load (viral load) and a decrease in CD4 cells. 


\subsection{Acquired Immunodeficiency Syndrome (AIDS)}

This stage is the most severe in HIV infection (figure 5). At this stage, the CD4 cell count drops dramatically to below 200 cells $/ \mathrm{mm}^{3}$, and in AIDS conditions, it will make PLWHA easily susceptible to opportunistic infections. Research involving 73 PLWHA from 2007-2013 in Banda Aceh found that the lower the CD4 cell count, the higher the incidence of opportunistic infections. The results found that tuberculosis was experienced by 30 samples ( 20 cases were found at CD4 pada 49cell / $\mathrm{mm}^{3}$ levels), chronic diarrhea as many as 24 examples ( 9 cases were found at $\mathrm{CD} 4 \leq 49 \mathrm{sel} / \mathrm{mm} 3$ levels) and oral candidiasis were 21 samples ( 13 cases were found at CD4 pada49 cell / mm3) level [34]. Another study conducted in Korea from 2006-2013 involving 1086 HIV patients from 19 hospitals, found that opportunistic infections such as candidiasis were 176 cases (16.2\%), 121 PCP cases (11.0\%), 120 TB cases (10.9\%), cytomegalovirus infections 52 cases (4.7\%), and herpes zoster 44 cases (4.0\%). Cases of Kaposi sarcoma and toxoplasmosis were the lowest cases, which were $8(0.7 \%)$ and $4(0.4 \%)$ cases respectively [35].

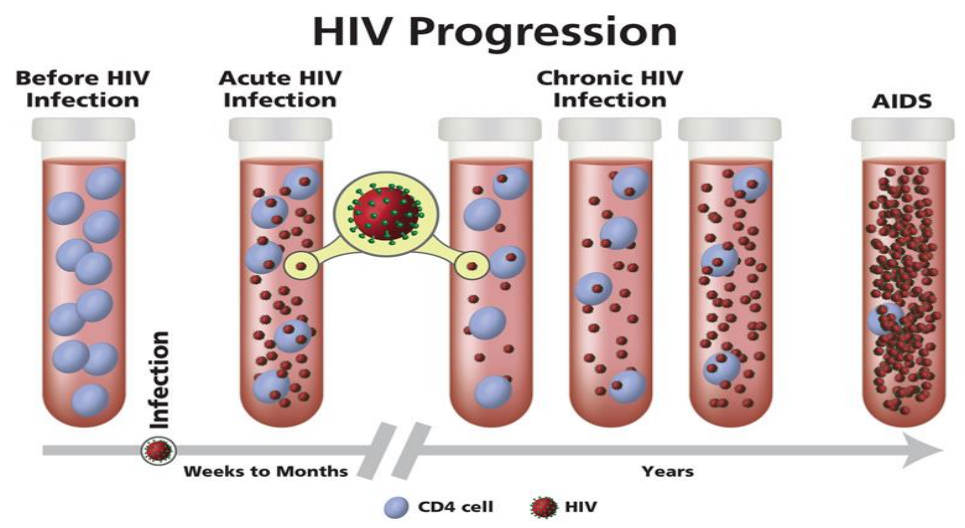

Figure 5 . When first (acute) infected with HIV, virus attacks and destroys immune cells (CD4 cells); after this phase the virus will be suppressed by the immune system so that the speed of viral replication decreases (asymptomatic / chronic); many years later without anti-HIV therapy, the virus begins to make even greater damage to the immune system so that the levels of the immune system decrease dramatically [33]

\section{Drug Resistance}

HIV drug resistance is one or more mutations (changes) of the genetic structure of HIV that affects specific drugs or combinations that block viral replication. WHO classifies three ways that HIV drug resistance is Acquired HIV Drug Resistance (ADR), which is resistance that comes from someone who is taking ARV; Transmitted HIV Drug Resistance (TDR), which is resistance to someone who is not infected with HIV but then infected from someone who has HIV drug resistance; and Pretreatment of HIV Drug Resistance (PDR), which is the presence of viral resistance when you have previously started ARV therapy. PDR can come from ADR or TD [36]. 
A review that reported genotype resistance from 9 studies from 8 countries, 4248 patients were evaluated. A total of 573 patients (13.5\%) experienced therapy failure for 12 months. as many as $60 \%$ of therapy failures are due to resistance in several classes of drugs. A meta-analysis that represented 56,044 samples of adult patients who experienced Non-Nucleoside Reverse Transcriptase Inhibitor resistance (NNRTI, one of the first-line types of HIV therapy) from 63 lower middle income countries, was estimated in 2016 of $11.0 \%$ (7.5 -15.9\%) cases of resistance occur in South Africa, 10.1\% (5.1-19.4\%) in East Africa, 7.2\% (2.9-16.5\%) in Central and Central Africa , 9.4\% (6.6-13.2\%) in Latin America and the Caribbean, and 3.2\% (1.8-5.6\%) in Asia [37].

HIV resistance can be caused by four factors, i.e. patient, stopping the consumption of ARV drugs is not what doctors recommend. This could have happened due to lack of understanding, side effects arising from ARV drugs; the program (government) is a challenge in country scale therapy. This factor concerns government relations in assisting the provision of ARV drugs; Therapy, inappropriate administration of treatment can increase the risk of ARV drug resistance. Fortunately, a fixed-dose combination drug is now available (in one drug consisting of several different medications), with this therapy, it is hoped that it can improve patient compliance with antiretroviral treatment; and viruses, the high speed of virus replication can enable the formation of new HIV subtypes that have the possibility of ARV resistance [38].

With the emergence of ARV resistance cases, it is expected to increase vigilance in handling cases of HIV infection. If HIV infection is accompanied by antiretroviral resistance this can disrupt immune system repair, decrease the effect of the work of antiretroviral drugs to increase mortality [39].

\section{Stigma and Discrimination}

Someone infected with HIV often experiences acts of stigma and discrimination. Recently discrimination was experienced by 14 elementary school students in Solo who were infected with HIV, and they were condemned by other parents of students to be expelled from their schools for fear of transmitting the disease to other healthy children [40]. Overseas, acts of discrimination were also experienced by someone infected with HIV. "My daughter refused to go to the hospital to get treatment. My daughter died because of fear of stigma and discrimination that was labelled by the community ". The sentence was said by a grandmother from Ghana who lost her daughter who is also a PLWHA [41].

A study involving data from 19 countries revealed that 1 in 5 (20\%) PLWHA were afraid of coming to the clinic because of the stigma and discrimination they received in the community [39]. If this stigma and discrimination were allowed to occur, this would result in delays in treatment of PLWHA and this will worsen the health condition of PLWHA. In a clinic in 
Namibia when stigma and discrimination were successfully eliminated, there was a $20 \%$ reduction in the mortality rate for people with HIV [42]. This decrease was due to the emergence of awareness and support from the public regarding the importance of treatment for PLWHA.

\section{Conclusion}

Since the discovery of the first case of HIV with opportunistic infections, until now, HIV infection is a severe health problem worldwide. HIV infection, also, to interfere with health, will disrupt the psychological sufferers. This is due to the stigma and discrimination they get from the community. If this stigma and discrimination are left unchecked, it will cause a person who is infected with HIV to delay treatment, and this will cause the condition of AIDS so that PLWHA more easily experience opportunistic infections. With the elimination of stigma and discrimination will help reduce mortality rates for PLWHA.

\section{REFERENCES}

[1] P. M. Sharp and B. H. Hahn, "Origins of HIV and the AIDS Pandemic," Cold Spring Harbor Perspectives in Medicine, vol. 1, no. 1, 2011.

[2] A Timeline of HIV and AIDS | HIV.gov. Available: https://www.hiv.gov/hivbasics/overview/history/hiv-and-aids-timeline[accessed: June 1, 2019]

[3] Z. Djoerban and S. Djauzi, "HIV/AIDS di Indonesia," In Buku Ajar Ilmu Penyakit Dalam, S. Setiati, I. Alwi, A. W. Sudoyo, M. K. Simadibrata, S. Setiyohadi, A. F. Syam, Eds. Jakarta: Interna Publishing, 2014, pp. 889-899.

[4] UNAIDS. Global HIV \& AIDS Statistics - 2019 Fact Sheet. Available: https://www.unaids.org/en/resources/fact-sheet[accessed: June 3, 2019]

[5] Kementerian Kesehatan Republik Indonesia. Hari AIDS Sedunia, Momen Stop Penularan HIV: Saya Berani, Saya Sehat!. 2018 Des. Available: http://www.depkes.go.id/article/view/18120300001/hari-aids-sedunia-momen-stop-penularan-hiv-saya-berani-saya-sehat.html [accessed: June 4, 2019]

[6] M. S. Cohen, Y.Q. Chen, M. McCauley, T. Gamble, M.C. Hosseinipour, N. Kumarasamy, et al, "Prevention of HIV-1 Infection with Early Antiretroviral Therapy," The New England Journal of Medicine, vol. 365, no. 6, pp. 493-505. 2011

[7] A. Gueler, A. Moser, A. Calmy, H. F. Günthard, E. Bernasconi, H. Furrer, et al, "Life Expectancy in HIV-Positive Persons in Switzerland: Matched Comparison with General Population," AIDS, vol. 31, no. 3, pp.427-436. 2017

[8] Centers for Diseases Control and Prevention. About HIV/AIDS | HIV Basics | HIV/AIDS | CDC. 2019 August. Available: https://www.cdc.gov/hiv/basics/whatishiv.html [accessed: June 5, 2019]

[9] Pusat Data dan Informasi Kementerian Kesehatan Republik Indonesia. InfoDatin Situasi dan Analisis HIV AIDS. 2014 Dec

[10] Kementerian Kesehatan Republik Indonesia. Laporan Situasi Perkembangan HIV AIDS \& PIMS di Indonesia, Januari-Maret 2019

[11] P. R. Murray, K. S. Rosenthal, M. A. Pfaller, Medical Microbiology. Philadelphia: Elsevier, 2016.

[12] D. Latuperissa, "Human Immundeficiency Virus," In Buku Ajar Infeksi \& Penyakit Tropis, S. R. S. Hadinegoro, I. Moedjito, M. M. D. Hapsari, A. Alam, Eds. Jakarta: Badan Penerbit Ikatan Dokter Anak Indonesia, 2018, pp. 267-281

[13] Nasronudin, "Virologi HIV," In Buku Ajar Ilmu Penyakit Dalam, S. Setiati, I. Alwi, A. W. Sudoyo, M. K. Simadibrata, S. Setiyohadi, A. F. Syam, Eds. Jakarta: Interna Publishing, 2014, pp. 900-903.

[14] K. C. Carroll, S. A. Morse, T. Mietzner, S. Miller, Jawetz, Melnick, \& Adelberg's Medical Microbiology. New York: McGraw-Hill Education, 2016. 
[15] P. Patel, E. Raizes, L. N. Broyles, "Human Immundeficiency Virus Infection," In Hunter's Tropical Medicine and Emerging Infectious Diseases, E. T. Ryan, D. R. Hill, T. Solomon, N. E. Aronson, T. P. Endy. Philadelphia: Elsevier, 2019, pp. 232-266.

[16] M. S. Reitz, R. C. Gallo, "Human Immunodeficiency Viruses", In Mandell, Douglas, and Bennett's Principle and Practice of Infectious Diseases, J. E. Bennett, R. Dolin, M. J. Blaser. Philadelphia: Elsevier, 2015, pp. 2202-2212.

[17] S. Nyamweya, A. Hegedus, A. Jaye, S. Rowland-Jones, K. L. Flanagan, D. C. Macallan, "Comparing HIV-1 and HIV-2 infection: Lessons for viral immunopathogenesis," Reviews in Medical Virology, vol. 23, no. 4, pp. 221-240. 2013

[18] M. Ndour, P. S. Sow, A. M. Coll-Seck, S. Badiane, C. T. Ndour, N. Diakhate, et al, "AIDS caused by HIV1 and HIV2 infection: are there clinical differences? Results of AIDS surveillance 1986-97 at Fann Hospital in Dakar, Senegal," Tropical Medicine \& International Health, vol. 5, no. 10, pp. 687-691. 2001

[19] C. Wejse, C. B. Patsche, A. Kuhle, F. J. Bamba, M. S. Mendes, G. Lemvik, et al, "Impact of HIV-1, HIV-2, and HIV-1+2 dual infection on the outcome of tuberculosis," International Journal of Infectious Diseases, vol. 32, pp. 128-134. 2015

[20] K. J. Ryan Eds., Sherris Medical Microbiology. New York: McGraw-Hill Education, 2018

[21] The HIV Life Cycle | Understanding HIV/AIDS | AIDSinfo. 2019 July. Available: https://aidsinfo.nih.gov/understanding-hiv-aids/fact-sheets/19/73/the-hiv-life-cycle [accessed: June 8, 2019]

[22] Paoli J. HIV Resistant Mutation. 2013 Oct. Available: https://www.nature.com/scitable/blog/viruses101/hiv_resistant_mutation/ [accessed: June 8, 2019]

[23] Kementerian Kesehatan Republik Indonesia. INFODATIN Situasi dan Analisis Penyalahgunaan Narkoba. 2014 June

[24] G. M. Shaw, E. Hunter, "HIV transmission," Cold Spring Harbor Perspectives in Medicine, vol. 2, no. 11. 2012

[25] J. delRomano, B. Marincovich, J. Castilla, S. Garcia, J. Campo, V. Hernando, et al, "Evaluating the Risk of HIV Transmission Through Unprotected Orogenital Sex,". AIDS, vol. 16, no. 9, pp.1296-1297. 2002

[26] S. Heron, S. Elahi, "HIV Infection and Compromised Mucosal Immunity: Oral Manifestations and Systemic Inflammation," Frontiers in Immunology, vol. 8, 241. 2017

[27] P. Patel, C. B. Borkowf, J. T. Brooks, A. Lasry, A. Lansky, J. Mermin, "Estimating peract HIV Transmission Risk: A Systematic Review," AIDS, vol. 28, no. 10, pp. 1509-1519. 2014

[28] R. C. Bailey, S. Moses, C. B. Parker, K. Agot, I. Maclean, J. N. Krieger, et al, "Male Circumcision for HIV Prevention in Young Men in Kisumu, Kenya: a Randomised Controlled Trial," Lancet, vol. 369, pp. 643-656. 2007

[29] B. Auvert, D. Taljaard, E. Lagarde, J. Sobngwi-Tambekou, R. Sitta, A. Puren, "Randomized, Controlled Intervention Trial of Male Circumcision for Reduction of HIV Infection Risk: The ANRS 1265 Trial," Plos Medicine, vol. 2, no. 11. 2005

[30] World Health Organization. Male Circumcision for HIV Prevention. Available: https://www.who.int/hiv/topics/malecircumcision/en/[accessed: June 9, 2019]

[31] A. S. Fauci, H. C. Lane, "Human Immunodeficiency Virus Disease: AIDS and Related Disorders," In Harrison's Principles of Internal Medicine, D. L. Kasper, S. L. Hauser, J. L. Jameson, A. S. Fauci, D. L. Longo, J. Loscalzo Eds. $19^{\text {th }}$ ed. New York: McGraw-Hill Education, 2015

[32] H. A. Weiss, K. E. Dickson, K. Agot, C. A. Hankins, "Male Circumcision for HIV Prevention: Current Research and Programmatic Issues," AIDS, vol. 4. 2010

[33] The Stages of HIV Infection | Understanding HIV/AIDS | AIDSinfo. 2019 June. Available: https://aidsinfo.nih.gov/understanding-hiv-aids/fact-sheets/19/46/the-stages-of-hiv-infection[accessed: June 10, 2019]

[34] K. F. Jamil, "Profil Kadar CD4 Terhadap Infeksi Oportunistik Pada Penderita Human Immunodeficiency Virus/ Acquired Immunodeficiency Syndrome (HIV/AIDS) di RSUD Dr. Zainoel Abidin Banda Aceh," Jurnal Kedokteran Syiah Kuala, vol. 14, no. 2, pp.76-80. 2014

[35] Y. J. Kim, J. H. Woo, M. J. Kim, D. W. Park, J. Y. Song, S. W. Kim, et al, “Opportunistic Diseases Among HIV-Infected Patients: A Multicenter-Nationwide Korean HIV/AIDS Cohort Study, 2006 to 2013," The Korean Journal of Internal Medicine, vol. 31, no. 5, pp. 953-960. 2016 
[36] HIV Drug Resistance Report 2019. Geneva, Switzerland: World Health Organization; 2019

[37] R. K. Gupta, J. Gregson, N. Parkin, H. Haile-Selassie, A. Tanuri, L. A. Forero, et al, "HIV1 Drug Resitance Before Initiation or re-Initiation of First-Line Antiretroviral Therapy in Low-income and Middle Income Countries: A Systematic Review and Meta Regression Analysis," The Lancet Infectious Diseases, vol. 18, no. 3, pp. 346-355. 2018

[38] Avert. HIV Drug Resistance. 2019 Jan. Available from: https://www.avert.org/professionals/hivprogramming/treatment/drug-resistance[accessed: June 13, 2019]

[39] R. L. Hamers, T. F. Rinke de Wit, C. B. Holmes, "HIV Drug Resistance In Low-Income and Middle-Income Countries," The Lancet HIV, vol. 5, no. 10. 2018

[40] BBC News Indonesia. 'Karena mengidap HIV/AIDS', 14 murid SD di Solo ditolak orangtua siswa. 2019 Feb. Available: https://www.bbc.com/indonesia/indonesia-47209632[accessed: June 14, 2019]

[41] UNAIDS. Feature story: Ghana-addressing the barrier of stigma and discrimination for women. 2017 Mar. Available: www.unaids.org/en/resources/presscentre/featurestories/2017/march/20170327_ghana[accessed: June 14, 2019]

[42] UNAIDS. Press-Release UNAIDS warns that HIV-related stigma and discrimination is preventing people from accessing HIV services. 2017 Oct. Available: www.unaids.org/en/resources/presscentre/pressreleaseandstatementarchive/2017/october/20171002_confrontingdiscrimination[accessed: June 14, 2019] 